\title{
Effects of Drying Methods on Anthocyanin Contents of Colored Barley (Hordeum vulgare L.) cv. Boanchalbori
}

\author{
Tae Hwa Song ${ }^{1}$, Tae II Park¹, Ouk kyu Han², Chang Yoon ${ }^{3}$, Hyen Jung Kang ${ }^{1}$ and Kuang Geun Park ${ }^{1}$ \\ ${ }^{1}$ Dept. Rice and Winter Cereal Crop, NICS, RDA, Iksan 570-080, Korea, ${ }^{2}$ National Institute of Crop Science, RDA, Suwon \\ 441-857, Korea, ${ }^{3}$ Dept. Animal bio, Chanbuk National University, Jeonju, 561-756, Korea
}

\begin{abstract}
This study investigated the effects of drying methods and drying time on the changes in anthocyanin content in colored barley. Colored barley cultivar Boanchalbori was harvested at a time when the anthocyanin content was the most and dried in afield. The harvested barley was then treated by two methods, sun drying and shade drying, for $4,8,24$, and $32 \mathrm{~h}$. The moisture content of the sun-dried barley decreased slightly faster than shade-dried samples, but the difference was not statistically significant. Chemical analysis indicated that the samples dried under shaded conditions had slightly higher crude fiber and lower nitrogen free extract, but the difference was not statistically significant. There was no difference in the total digestible nutrients between the two methods. In the case of sun-dried barley, the anthocyanin content decreased compared to the control and shade-dried samples after drying for $4 \mathrm{~h}(\mathrm{p}<0.05)$, was maintained at a constant level at $24 \mathrm{~h}$, and then decreased at $32 \mathrm{~h}$. In case of shade-dried barley, the anthocyanin content decreased gradually with the drying time, and a significant decrease was found at $24 \mathrm{~h}$ of drying $(\mathrm{p}<0.05)$ as compared to the control. The shade-dried method was more successful in reducing anthocyanin loss than the sun-dried method $(\mathrm{p}<0.05)$. There was a slight decrease in 1,1-Diphenyl-2-Picrylhydrazyl radical scavenging with drying time in the shade-dried method, and a significant decrease after $4 \mathrm{~h}$ with the sun-dried method. These results showed that covering with a two-layer awning was advantageous to dry colored barley in the field conditions.
\end{abstract}

(Key words : Colored barley, Anthocyanin, Drying method, Drying time)

\section{I . INTRODUCTION}

Gradually being advanced Korean economy and level of consciousness have been brought high-quality of dietary life and a keen interest in well-being foods, and consumption patterns of livestock products are recently changing from quantity to quality such as well-being functional foods or variety of clean meats. The production of functional meats is congenital quality of livestock but also influenced by the energy source for livestock and feedstuff. Thereby, the development of functional feedstuff for high-quality functional meat production is recently proceeding world-widely (Jang et al., 2010; Cho et al., 2010). One of functional components of plant body, a reddish natural pigment, anthocyanin is widely contained in each of flowers, fruits, stems, leaves, and roots of higher plants, and it is also composed of anthocyanidine and sugar. Anthocyanin, as a kind of naturally existing water-soluble flavonoid pigment, is known to aid anti-cancer, anti-allergy, anti-virus, improvement of immune system (Harborne, 1988; Prior et al., 2005; Kong et al., 2003; Yang et al., 2001; Harbonrne\& William, 2000). Therefore, it will be beneficial in production of livestock by reinforcing the immune system of livestock through developing rough feedstuff that contains anthocyanin. Forage barley has been cultivated in Korea by using winter paddy for the production of whole feedstuff which contains seed, leaves, and stems. It is not only to replace general rough feedstuffs but also for partial replacement of feedstuffs for monogastrics (Lee et al., 1994; Park et al., 2008). In Rural Development Administration, Boanchalbori barley, which contains high contents of anthocyanin, was developed recently. It will show high usage as a functional feedstuff. Manifestation mechanism of anthocyanin is extremely complexed, it gets influenced not only by genetic elements but also by numerous environmental factors such as light, temperature, moisture, and nitrogen contents in the body.

* Corresponding author: Tae-Hwa Song, National Institute of Crop Science, RDA, Iksan, Korea, Tel: +82-63-840-2145, Fax: +82-63840-2116, Email: ocean0916@korea.kr 

greatly influenced by drying environment and storages after the cultivation. Because drying process is necessary for the use of colored barley as a feedstuff for livestock, this study was accomplished to investigate the change of anthocyanin contents in accordance with drying in the sun and the shade, and drying hours under the certain field condition after the cultivation of colored barley.

\section{П. MATERIALS AND METHODS}

\section{Sample making and analysis}

Boanchalbori (Hordeumvalgare L.), a colored barley cultivar, used in this study was developed at NICS, RDA, in Korea. The cultivars Boanchalbori were harvested at a time of accumulated anthocyanin more stages (35 to 40 days after heading) and dried in the field conditions. The drying condition was naturally sun-dried and shade-dried (cover with two layers awning dried: transmittancy, 50\%), and the drying time was respectively at 4, 8, 24 and $32 \mathrm{hr}$. After $1 \mathrm{~kg}$ by taking samples every hour, and dried 72 hours or more circulating drying machine $50^{\circ} \mathrm{C}$, weighed, calculating the content of dry matter, were used for analysis by pulverizing it. The crude protein $(\mathrm{CP})$, ether extract $(\mathrm{EE})$, crude ash (CA), nitrogen free extract (NFE), crude fiber $(\mathrm{CF})$, neutral detergent fiber (NDF) and acid detergent fiber (ADF) were measured by the methods of AOAC (2000) and Van Soest et al. (1991). Total digestible nutrients (TDN) was calculated using the formula $\operatorname{TDN}(\%)=88.9-(0.79 \times$ \%ADF) (Holland, 1990). For the anthocyanin content analysis, the $0.2 \mathrm{~g}$ samples were mixed with $2 \mathrm{ml} 0.01 \mathrm{~N}$ HCI- $80 \%$ Methanol solution and extracted at $4^{\circ} \mathrm{C}$ in a shaking incubator for $24 \mathrm{hr}$. The extract which was passed through a 0.2 um syringe filter was determined by high-performance liquid chromatography (HPLC). The HPLC conditions for the analysis of anthocyanins were shown in Table 1.
Additionally, anthocyanin content in plant body is also

Table 1. HPLC conditions for the analysis of anthocyanins

\begin{tabular}{ll}
\hline Items & Conditions \\
\hline \hline Column & YMC-Pack ODS-AM \\
Detector & $\mathrm{UV}, 520 \mathrm{~nm}$ \\
Flow rate & $0.9 \mathrm{ml} / \mathrm{min}$ \\
Solvent & A: $5 \%$ formic acid \\
Absorbance & B: Acetonitrile + formic acid \\
Injection volume & $520 \mathrm{~nm}$ \\
\hline
\end{tabular}

Measurement of antioxidant capacity was carried out using 1,1-Diphenyl-2-Picrylhydrazyl (DPPH) as a free radical. Reduction of DPPH by an antioxidant or a free radical produces decreased absorbance at $515 \mathrm{~nm}$. 100uL of the extract were mixed with $100 \mathrm{uL}$ DPPH $(0.4 \mathrm{mMol})$. After 10 min, the plate was reed at $517 \mathrm{~nm}$ in a spectrophotometer. The analysis was performed in triplicate.

\section{Statistical analysis}

The data of this experiment was subjected to SAS Ver. 9.1 program and statistically significant differences among means were determined using Duncan's multiple range test at $5 \%$ probability (SAS, 2002).

\section{RESULTS AND DISCUSSION}

\section{Agronomic characteristics and Productivity of colored barley}

The agronomic characteristics and productivity of colored barley were shown in Table 2. For the agronomic characteristics, plant height and spike length were respectively $86 \mathrm{~cm}$ and $3.0 \mathrm{~cm}$ and heading date was at April 23. In the productivity, fresh yield was 25 ton/ha, dry matter yield and TDN yield were 12 and 8 ton/ha, respectively.

Table 2. Agronomic characteristics and productivity of colored barley

\begin{tabular}{|c|c|c|c|c|c|c|c|}
\hline \multirow[b]{2}{*}{ Cultivar } & \multirow{2}{*}{$\begin{array}{l}\text { Heading } \\
\text { date }\end{array}$} & \multicolumn{3}{|c|}{ Agronomic characteristics } & \multicolumn{3}{|c|}{ Forage productivity (Ton/ha) } \\
\hline & & $\begin{array}{l}\text { Plant height } \\
(\mathrm{cm})\end{array}$ & $\begin{array}{l}\text { Spike length } \\
(\mathrm{cm})\end{array}$ & $\begin{array}{l}\text { No. of tillers } \\
\text { per } \mathrm{m}^{2}\end{array}$ & Fresh & Dry & $\begin{array}{l}\text { TDN } \\
\text { yield }\end{array}$ \\
\hline Boanchalbori & April 23 & 86 & 3.5 & 689 & 24.8 & 11.8 & 8.3 \\
\hline
\end{tabular}




\section{Moisture content}

Changes of moisture content according to drying method and time were shown in Fig. 1. In the drying method, moisture content of naturally sun-dried samples was decreased slightly faster than shade-dried samples, but did not show a significantly different, statistically. After drying $8 \mathrm{hrs}$, the moisture content of sun-dried and shade-dried samples were decreased $42.3 \%$ and $43.5 \%$ respectively, comparing to $57.1 \%$ at harvesting. And, the moisture content was decreased to $35.8 \%$ and $37.2 \%$ after drying $32 \mathrm{hrs}$. It is possible to produce a powder sample using a pulverizer for make feed of livestock. Freeze-drying or machine drying is usually used to make dried samples, but those methods are high cost and low practicality. However, drying in the field is suitable method for large quantity of samples. In this study, it is necessary to minimize the loss of anthocyanin content in Boanchalbori, thus it is dried with covering with awning. Using two layers of awning resulted in no significant difference between the natural drying.

\section{Chemical compositions}

Changes in chemical compositions of colored barely according to drying method and time were shown in Table 3. In the drying time, crude fiber content showed slightly

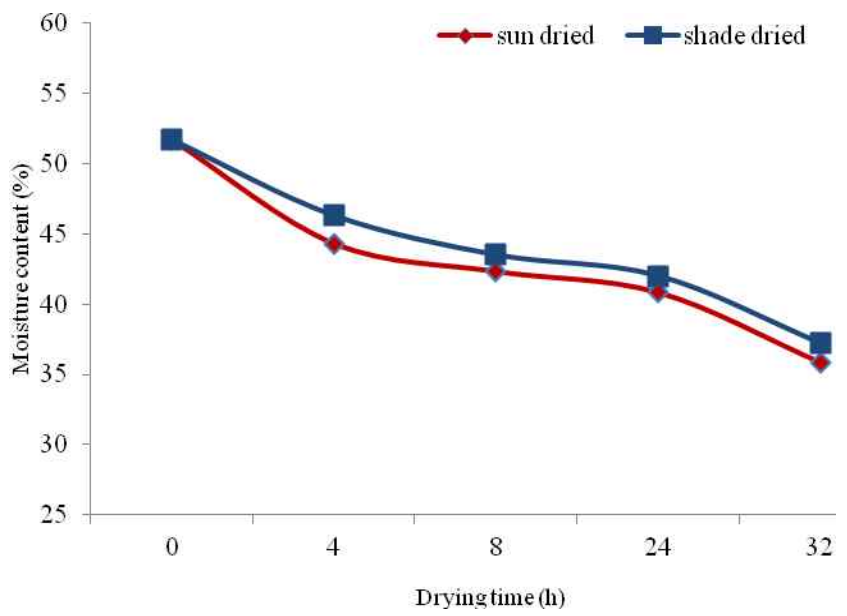

Fig. 1. Changes of moisture content according to drying method and time in colored barley.

higher than the control sample and nitrogen free extract content was lower compared to the control sample but not significantly different. The other compositions were at similar levels with prolonged drying time and TDN content at the first levels. In the drying method, all components in both the sun and shade dried of samples were similar levels. Fiber as a component of cell walls that form the plant structure is related to intake and digestibility with the role of feel a sense of fullness in livestock. Kim et al. (2006) reported that crude fiber content was increased with prolonged wilting period but other components did not show any trends. The crude fiber content of oat cultivar

Table 3. Changes in chemical compositions according to drying method and time in colored barley

\begin{tabular}{|c|c|c|c|c|c|c|c|c|c|}
\hline \multirow{2}{*}{$\begin{array}{l}\text { Drying } \\
\text { method }\end{array}$} & \multirow{2}{*}{$\begin{array}{l}\text { Drying Time } \\
\text { (h) }\end{array}$} & \multicolumn{8}{|c|}{ Chemical composition $(\%)$} \\
\hline & & $\mathrm{CP}^{1)}$ & $\mathrm{EE}$ & $\mathrm{CA}$ & NFE & $\mathrm{CF}$ & $\mathrm{NDF}$ & $\mathrm{ADF}$ & TDN \\
\hline & 0 & 6.5 & 1.9 & 7.1 & 56.3 & 21.7 & 46.9 & 24.9 & 69.2 \\
\hline \multirow{5}{*}{ Sun-dried } & 4 & 6.4 & 2.0 & 6.9 & 54.7 & 22.9 & 46.7 & 25.0 & 69.1 \\
\hline & 8 & 6.4 & 2.1 & 6.7 & 54.9 & 22.9 & 47.4 & 25.3 & 68.9 \\
\hline & 24 & 6.3 & 2.0 & 6.8 & 53.5 & 23.6 & 45.1 & 24.4 & 69.6 \\
\hline & 32 & 6.3 & 2.1 & 6.7 & 54.1 & 23.8 & 46.7 & 24.8 & 69.3 \\
\hline & Mean & 6.4 & 2.0 & 6.8 & 54.3 & 23.3 & 46.5 & 24.9 & 69.2 \\
\hline \multirow{5}{*}{ Shade-dried } & 4 & 6.4 & 2.3 & 6.7 & 54.7 & 22.6 & 46.7 & 25.2 & 69.0 \\
\hline & 8 & 6.4 & 2.2 & 6.8 & 55.2 & 22.4 & 46.2 & 24.0 & 69.9 \\
\hline & 24 & 6.3 & 2.0 & 6.8 & 55.3 & 22.6 & 47.6 & 25.2 & 69.0 \\
\hline & 32 & 6.2 & 2.1 & 6.6 & 54.3 & 23.8 & 47.0 & 25.0 & 69.2 \\
\hline & Mean & 6.3 & 2.2 & 6.7 & 54.9 & 22.9 & 46.9 & 24.9 & 69.3 \\
\hline
\end{tabular}

${ }^{1)}$ CP: crude protein, EE: Ether extract, CA: Crude Ash, NFE: Nitrogen Free extract, CF: Crude Fiber, NDF: neutral detergent fiber, ADF: acid detergent fiber, TDN: total digestible nutrients. 
was increased as the curing progressed, and the difference of crude fiber content of oat cultivar was maintained through the whole curing period (Han and Kim, 1996). But Gordon (1981) also reported that crude fiber content was not significantly different wilting treatments of herbage. In this study, fiber contents were not changed with prolonged drying period.

\section{Anthocyanin content}

Changes in anthocyanin content of colored barley

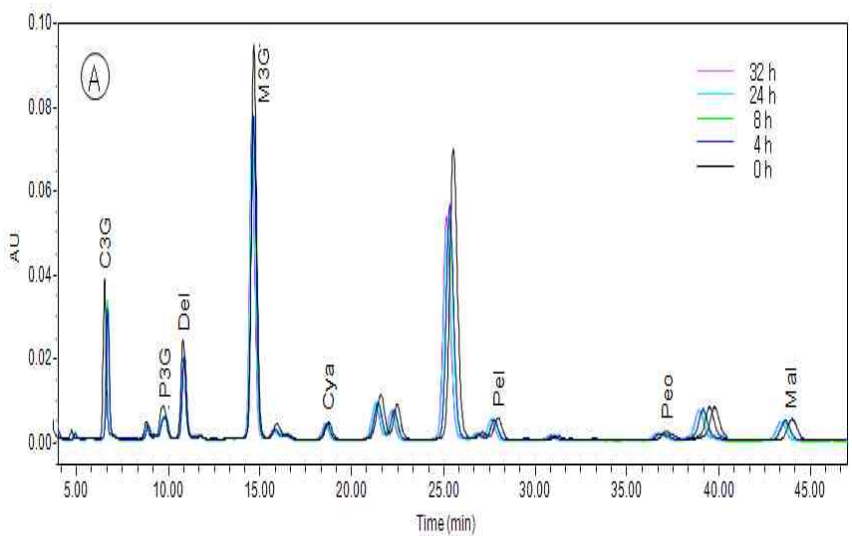

according to drying method and time were shown in Fig. 2 and Table 4. In case of sun-dried, cyaniding-3-glucoside (C3G), Perlargonidin-3-glucoside (P3G), delphinidin (Del), and malvidin-3-gluciside (M3G) contents were significantly decreased compared to the control and shade-dried samples at the after drying $4 \mathrm{hrs}(<0.05)$, however they were maintained at the constant levels up to $24 \mathrm{hrs}$. But a significant decreased was found at $32 \mathrm{hrs}$ of drying $(\mathrm{p}<0.05)$. Other anthocyanin components were maintained at the first levels. In case of shade-dried, anthocyanin content showed gradually decrease in accordance with the drying time and significantly

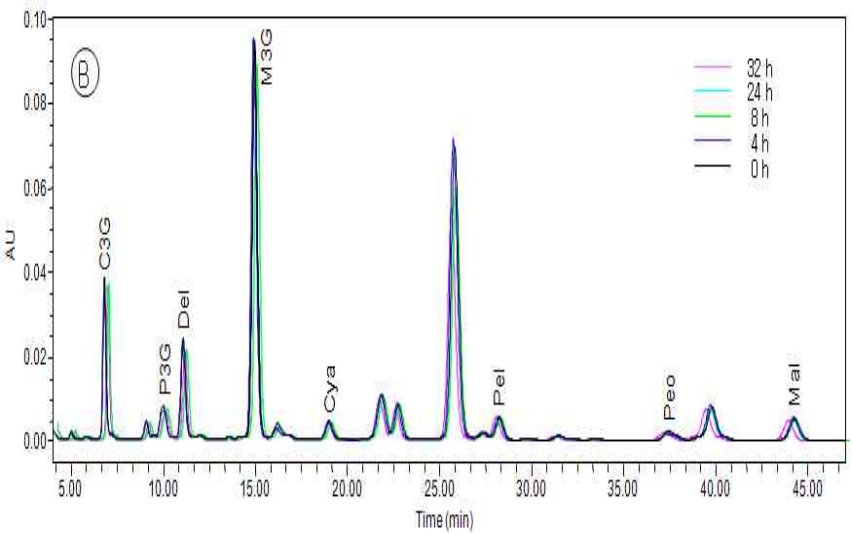

Fig. 2. Anthocyanins of different drying method detected by HPLC.

(A) Sun-dried and (B) Shade-dried

Table 4. Changes in anthocyanin content according to drying method and time in colored barley

\begin{tabular}{|c|c|c|c|c|c|c|c|c|c|c|}
\hline \multirow{2}{*}{$\begin{array}{l}\text { Drying } \\
\text { method }\end{array}$} & \multirow{2}{*}{$\begin{array}{c}\text { Drying } \\
\text { Time } \\
(\mathrm{h}) \\
\end{array}$} & \multicolumn{9}{|c|}{ Anthocyanin content (mg/g) } \\
\hline & & $\mathrm{C} 3 \mathrm{G}^{1)}$ & $\mathrm{P} 3 \mathrm{G}$ & Del & $\mathrm{M} 3 \mathrm{G}$ & Cya & Pel & Peo & Mal & Total \\
\hline & 0 & $0.177^{\mathrm{a}}$ & $0.037^{\mathrm{a}}$ & $0.116^{\mathrm{a}}$ & $0.558^{\mathrm{a}}$ & 0.040 & 0.026 & 0.024 & 0.067 & $1.043^{\mathrm{a}}$ \\
\hline \multirow{5}{*}{$\begin{array}{l}\text { Sun- } \\
\text { dried }\end{array}$} & 4 & $0.156^{\mathrm{b}}$ & $0.028^{\mathrm{c}}$ & $0.096^{\mathrm{c}}$ & $0.452^{\mathrm{c}}$ & 0.035 & 0.024 & 0.023 & 0.062 & $0.877^{\mathrm{c}}$ \\
\hline & 8 & $0.152^{\mathrm{b}}$ & $0.030^{\mathrm{b}}$ & $0.093^{\mathrm{d}}$ & $0.449^{\mathrm{c}}$ & 0.036 & 0.025 & 0.021 & 0.061 & $0.866^{\mathrm{c}}$ \\
\hline & 24 & $0.155^{\mathrm{b}}$ & $0.029^{c}$ & $0.092^{\mathrm{d}}$ & $0.452^{\mathrm{c}}$ & 0.036 & 0.026 & 0.021 & 0.060 & $0.871^{\mathrm{c}}$ \\
\hline & 32 & $0.146^{\mathrm{c}}$ & $0.028^{\mathrm{c}}$ & $0.092^{\mathrm{d}}$ & $0.440^{\mathrm{d}}$ & 0.035 & 0.024 & 0.021 & 0.061 & $0.847^{\mathrm{d}}$ \\
\hline & Mean & $0.152^{\mathrm{B}}$ & $0.028^{\mathrm{B}}$ & $0.093^{\mathrm{B}}$ & $0.448^{\mathrm{B}}$ & 0.035 & 0.025 & 0.022 & 0.061 & $0.865^{\mathrm{B}}$ \\
\hline \multirow{5}{*}{$\begin{array}{c}\text { Shade- } \\
\text { dried }\end{array}$} & 4 & $0.179^{\mathrm{a}}$ & $0.032^{\mathrm{ab}}$ & $0.117^{\mathrm{a}}$ & $0.562^{\mathrm{a}}$ & 0.040 & 0.027 & 0.022 & 0.060 & $1.039^{\mathrm{a}}$ \\
\hline & 8 & $0.173^{\mathrm{a}}$ & $0.035^{\mathrm{a}}$ & $0.109^{\mathrm{a}}$ & $0.555^{\mathrm{a}}$ & 0.037 & 0.026 & 0.020 & 0.061 & $1.016^{\mathrm{a}}$ \\
\hline & 24 & $0.170^{\mathrm{a}}$ & $0.033^{\mathrm{ab}}$ & $0.101^{\mathrm{b}}$ & $0.509^{b}$ & 0.037 & 0.025 & 0.019 & 0.060 & $0.955^{\mathrm{b}}$ \\
\hline & 32 & $0.170^{\mathrm{a}}$ & $0.031^{b}$ & $0.100^{\mathrm{b}}$ & $0.493^{\mathrm{b}}$ & 0.037 & 0.027 & 0.020 & 0.062 & $0.938^{\mathrm{b}}$ \\
\hline & Mean & $0.173^{\mathrm{A}}$ & $0.033^{\mathrm{A}}$ & $0.106^{\mathrm{A}}$ & $0.522^{\mathrm{A}}$ & 0.038 & 0.026 & 0.020 & 0.063 & $0.981^{\mathrm{A}}$ \\
\hline
\end{tabular}

${ }^{\mathrm{a}-\mathrm{d}}$ Means in the same column with different superscripts are significantly different $(\mathrm{p}<0.05)$.

${ }^{1)}$ C3G:cyanidin-3-glucoside, P3G:pelargonidin-3-glucoside, Del:delphinidin, M3G:malvidin3-O-glucoside, Cya:cyanidin, Pel:pelargonidin, Peo: peonidin, Mal: malvidin. 
decreased as compared to the control after $24 \mathrm{hrs}(\mathrm{p}<0.05)$. Comparing sun and shade drying methods, shade drying method significantly reduced anthocyanin loss than sun drying method $(\mathrm{p}<0.05)$. The factors of light, high temperature, oxygen and high $\mathrm{pH}$ were associated with anthocyanin stability (Francis, 1989; Mazza and Miniati, 1993). Jenshiroobha et al. (2011) also reported that increasing in $\mathrm{pH}$, temperature and exposure to light is able to spoil the anthocyanin molecule. In this study, sun-dried samples were exposed to sun and shade-dried also has been continued with the impacts of light, because of transmittance to $50 \%$ of awning. Because anthocyanin pigments was easily decomposed in the light, in the case of sun-dried and greatly reduced according to drying time but, anthocyanin pigments showed the results of a relatively small reduction in the case of shade-dried.

\section{DPPH radical scavenging}

Effects of scavenging DPPH Radical by ethanol extract of colored barley according to drying method and time were shown in Fig 3. The DPPH radical scavenging was slightly decreased according to drying time in shade-dried. But in the sun-dried, it was significantly decreased after 4 hrs, thereafter slightly decreased with drying time. Antioxidant activity showed higher when the content of anthocyaninsis high, but antioxidant activity showed lower as the content

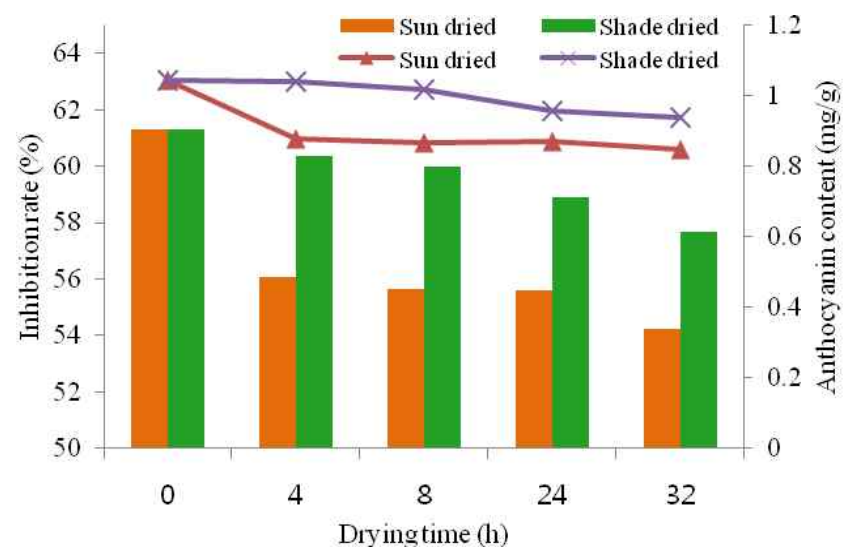

Fig. 3. Scavenging effects of DPPH radical by ethanol extract according to drying method and time in colored barley.

- Bar chart: Inhibition rate (\%); line chart: Anthocyanin content $(\mathrm{mg} / \mathrm{g})$. of anthocyanins was low. Song et al. (2005) reported that antioxidation ability as the content of anthocyanins is high and anthocyanin content has a significant relationship on antioxidant activity. Maritza et al. (2013) reported that the antioxidant activity of strawberries was directly correlated with anthocyanin content in the fruit. In this study, antioxidant activity and anthocyanin content have a positive correlation.

These results showed that if dry in shade without changing chemical compositions can prevent a decrease in anthocyanin content. Therefore, it is advantageous when it's dried and covered with a two-layerawning in the field conditions the colored barley for feedstuff.

\section{ACKNOWLEDGMENTS}

This study was supported by a Postdoctoral Fellowship Program of National Institute of Crop Science (NICS), Rural Development Administration (RDA), Republic of Korea, and a grant from "Cooperative Research Program for Agricultural Science \& Technology Development (Project No. PJ007435)", RDA, Republic of Korea.

\section{REFERENCES}

AOAC. 2000. Official methods of analysis of AOAC International, 17th eds. AOAC International, Gaithersburg, MD.

Cho, S.K., Jo, C.H., Jung, S., Kim, M.K., Oh, H.M., Lee, B.D. and Lee, S.K. 2010. Effects of Dietary Quercetin on the Feed Utilization, Blood Parameters, and Meat Quality in Korean Native Goats. Journal of Animal Science and Technology. 52: 297-304.

Francis, F. 1989. Food colourants: Anthocyanins. Critical. Reviews in Food Science and Nutrition. 28:273-314.

Gordon, F.J. 1981. The effect of wilting of herbage on silage composition and its feeding value for milk production. Animal production. 32:171-178.

Han, K.J. and Kim, D.A. 1996. Effect of cultivar, drying agent and preservative on quality changes of fall harvested oat hay. Journal of the Korean Society of Grassland and Forage Science. 16: 315-326.

Harborne, J.B. 1988. Introduction to ecological biochemistry (3rd ed.). Academic press, London.

Harborne, J.B. and Wiliam, C.A. 2000. Advances in flavonoid 
research since 1992. Phytochem. 55:481-504.

Holland, C., Kezar, W., Kautz, W.P., Lazowski, E.J., Mahanna, W.C. and Reinhart, R. 1990. Pioneer Hi-Bred International, Inc., Des moines, IA.

Jang, H.D., Lee, J.H., Hong, S.M., Jung, J.H. and Kim, I.H. 2010. Effects of Supplemental Medicinal Plants (Artemisia, Acanthopanax and Garlic) onProductive Performance of Sows and on Growth and Carcass Traits in Finishing Pigs. Journal of Animal Science and Technology. 52:103-110.

Jenshiroobha, J., Saravanakumar, M., Aravindhan, K.M. and Suganyadevi, P. 2011. The effect of light, Temperature, $\mathrm{pH}$ on stability of anthocyanin pigments in Musa acuminate bract. Research in plant biology. 1:05-12.

Kim, J.G., Chung, E.S., Seo, S., Ham, J.S., Kim, M.J. and Lee, J.K. 2006. Effect of Wilting Day on the Quality of Round Baled Grass Silage. Journal of the Korean Society of Grassland and Forage Science. 26:39-44

Kong, J.M., Chia, L.S., Goh, N.K., Chia, T.F. and Brouillard, R. 2003. Analysis and biological activities of anthocyanins. Phytochem. 64:923-933.

Lee, J.H., Lee, K.H., Rhee, Y.C. and Ohh, S.J. 1994. Effects of the Addition of $\beta$-Glucanase to Barley - based Layer Diet. Journal of the Korean Society of Poultry Science. 21:195-205.

Maritza, A.M., Anaberta, C.M., Sabah, M., Gerardo, M.G. and Karim, A. 2013. Comparative study of the effects of drying methods on antioxidant activity of dried strawberry (Fragaria Var.
Camarosa). Journal of Food Research. 2:92-107.

Mazza, G. and Miniati, E. 1993. Anthocyanins in fruits, vegetablesand grains. CRC Press, Boca Raton, FL.

Park, T.L., Han, O.K., Seo, J.H., Choi, J.S., Park, K.H. and Kim, J.G. 2008. New barley cultivars whitimproved morphological characteristics for whole crop forage in Korea. Journal of the Korean Society of Grassland and Forage Science. 28:193-202.

Prior, R.L., Wu, X. and Schaich, K. 2005. Standardized method for determination of antioxidant capacity and phenolics in foods and biological and food samples. Journal of Agricultural and Food Chemistry. 53:4290- 4302 .

SAS. 2002. SAS system Release 9.1, SAS Institute Inc., Cary, NC.

Song, S.E., Park, S.J., Woo, N.R.A., Won, M.H., Choi, J.S., Kim, J.G. and Gang, M.H. 2005. Antioxidant capacity of colored barley extracts by varieties. Journal of Food Science and Nutrition. 34:1491-1497.

Van Soest, P.J., Robertson, J.B. and Lewis, B.A. 1991. Methodsfor dietary fiber, neutral detergent fiber, and nonstarchpolysaccharides in relation to animal nutrition. Journal of Dairy science. 74:35833597.

Yang, C.S., Landau, J.M., Huang, M.T. and Newmark, H.L. 2001. Inhibition of carcinogenesis by dietary polyphenolic compounds. Annual Review of Nutrition. 21:381-406.

(Received July 10，2013/Revised November 10，2013/Accepted November 15, 2013) 